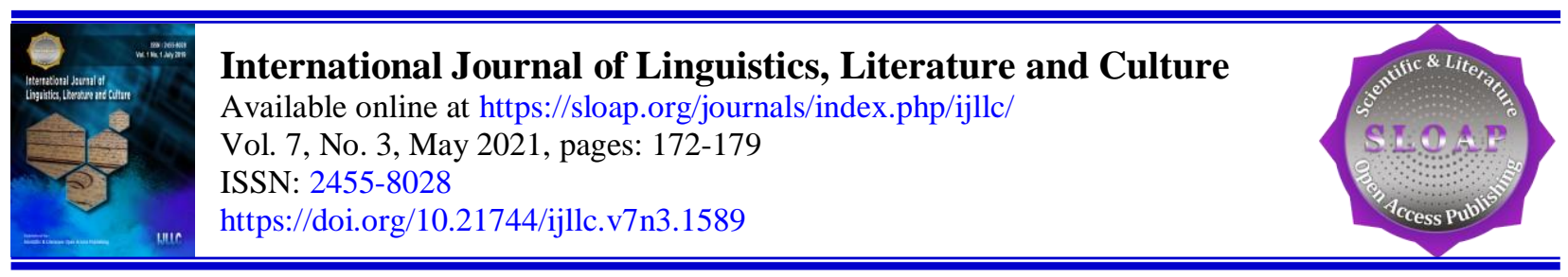

\title{
Pekatik in Gambuh Dramatic Show
}

I Wayan Budiarsa ${ }^{\text {a }}$

Article history:

Submitted: 9 February 2021

Revised: 18 March 2021

\section{Keywords:}

gambuh;

horse keeper;

pekatik;

servant;
Accepted: 27 April 2021

\begin{abstract}
A dramatic performance that presents a play will be found by several figures according to their social status, which is a reflection of people's lives that are staged on the stage. Gambuh, for example, as the mother of the Balinese drama that appeared afterward and has developed from the Ancient Bali era, Classical Bali to the present, there are at least several strata of characters that appear, one of which is the Pekatik actor. This servant character only appears according to the needs of the storyline being presented, has the character of being innocent, funny, and antawacana using Balinese. Now, in some Gambuh performances, the Pekatik character is very rare because after the 1990s this role was replaced by the Semar character. This study is very important as a source of written data that will be used as reference material for future researchers. This research uses qualitative methods, as well as data collection using literature review techniques, documentation, and interviews.
\end{abstract}

International journal of linguistics, literature and culture (C) 2021. This is an open access article under the CC BY-NC-ND license (https://creativecommons.org/licenses/by-nc-nd/4.0/).

\section{Corresponding author:}

Budiarsa, I. W.

Postgraduate Program, Art Study Program, Doctoral Program, ISI Denpasar, Indonesia

Email address: wayanbudiarsa1973@gmail.com

${ }^{\text {a }}$ Postgraduate Program, Art Study Program, Doctoral Program, ISI Denpasar, Indonesia 


\section{Introduction}

The Panji epic in Bali known as Malat, is a product of the XI century, a story that originally appeared in the archipelago (Kediri) and spread to Southeast Asia with several names of its central figures such as Inu, Inu Kertapati, or Inau/Inou. The Panji/Malat story is used as a drama performance art play called Gambuh. Majapahit's greatness and power played a major role in the spread of this story so that it was also known in several countries such as Thailand, Cambodia, Malaysia, and Myanmar. When the king has full power, its spread is through diplomatic relations in the arts and culture where Java is the place for the emergence of major kingdoms in the archipelago. Formaggia (2000a) stated that Gambuh has a close relationship with the Panji story which is also found in the Malay Peninsula and throughout the archipelago and even to Southeast Asia. Malat is the source of the Gambuh story in Bali and is from one source, namely from Java. Although the Panji stories originate from one source, this does not mean that the Balinese Panji (Malat) stories will be the same as the Panji stories in Siam, Burma, and Cambodia. The difference is there, Panji's story undergoes a modification according to the cultural background of the community in which Panji's story lives and develops (Bandem, 1996; Brysse et al., 2013).

The Panji story tells the audience about the ins and outs of the palace, among other things, how politics works, the role of women, the emotional life of the rulers or those on the threshold of power, manners, dress, and actions. The treasures of the Panji story discuss the various palaces that live side by side, and the movements, marriages, or conflicts between the palaces. Provides a list of past and present palaces, outlining the plurality in the complex kinship relations between members of the palace. The Panji story is a model for the palaces in interacting with subjects and is also a historical treasure that is used as a benchmark for assessing the character of princes (Vickers, 2009). It seems that the Ramayana and Mahabharata as famous epics from India have developed earlier in the archipelago so that the Panji story is a counter-story to the existence of the epic from the Indian state. These epics adapt to the cultural traditions of the Indonesian people, dissolving in every activity of people's lives in the form of literary arts, fine arts, performing arts, and so on.

Literary art is an inner expression that is expressed in a beautifully written form. In terms of aesthetics, the literature focuses more on emotional power concerning the world of life. Only a small part is an expression of a pure feeling of beauty (Bastomi, 1992). Literary art is a treasure trove of Indonesian literature which is actualized either in oral or written form. In Bali, literary art was originally written on palm leaves which were categorized into the Balinese Purwa literary period covering all the old manuscripts that were traditionally inherited to the present. In addition to writing on palm leaves, earlier literary media also used copper plates or on stone. Meanwhile, literature that has used paper media is categorized into the Balinese New/Modern literary period. As we know, some Balinese literary heritage generally uses Kawi/Old Javanese, Middle Javanese, and Balinese. Fine art is a type of art that exists apparently, meaning that its form can be sensed with the eye and touched. Therefore, art is also called visual art (Bastomi, 1992). Performing arts is a work of art to express creativity, taste, a human initiative that contains aesthetic values, whether presented individually or in groups, and displayed in a room/place within a certain time by involving various types of artworks. Performing arts include dance, musical arts, puppets, music, and drama/theater (Demircioğlu, 2010; Harris \& Willoughby, 2009).

Some of the variants of art above grow and develop in society to meet the needs of human life both in the form of primary and secondary needs which include the functioning of art as a ceremony, entertainment, and meet economic needs. In the Bali region, in particular, Balinese arts can be classified into Wali art, Bebali art, and Balih-balihan art. The art of guardianship, the field of dance performance is a dance that is presented in conjunction with a procession of piodalan ceremony at a temple in Bali. This dance will be performed on the main page of the temple (jeroan/utama mandala) which at the same time we will also meet a priest chanting the Veda prayer as the conductor of the ceremony. The dances are included as guardians, namely Baris Gede, Rejang Dewa, and Topeng Pajegan. Bebali dance, is a dance that is served as a ceremony accompaniment which is still associated with the piodalan ceremony at a temple. The dances that are classified as Bebali, namely; Gambuh and Wayang Wong. In general, the performances take place in the middle courtyard (madya mandalaljaba tengah) at a temple. Here, the dancer and the audience will mingle without any separation, so that on this occasion the audience is not only presented with dance but indirectly the audience can be enlightened (knowledge), especially regarding the contents of Hindu religious literature that is discussed by servant/punakawan.

Not apart from the storyline that was delivered, the literary fibers conveyed were usually about spirituality, philosophy in living life in the world to the hereafter. Balih-balihan dance, which is a dance that is served only as entertainment, is not tied to the ceremonial procession but is still related to the running of the piodalan ceremony at a

Budiarsa, I. W. (2021). Pekatik in gambuh dramatic show. International Journal of Linguistics,

Literature and Culture, 7(3), 172-179.

https://doi.org/10.21744/ijllc.v7n3.1589 
temple in Bali. Jaba sisi/nista mandala is a place for performing dances classified as balih-balihan. The balihbalihhan dance groups include; legong dance, freelance/popular dance, as well as new creation dances. In the context of tourism, the Genggong dance, Barong Kunti Sraya dance, the Fire Dance (derived from the Sanghyang dance) are entertainment dances which in their presentation are not bound by time and space, because they can be performed at any time according to the audience's request. As Sedyawati (1981) stated that performing arts, especially in the form of dances accompanied by sounds, are often carriers of magical powers that are expected to be present, but also not infrequently they are merely signs of gratitude for their occurrence and certain events. Some of the functions of performing arts in ethnic circles in Indonesia as summoning supernatural powers, gathering protective spirits to be present at the place of worship, summoning good spirits to ward off evil spirits, warning the ancestors by imitating both prowess and alertness, complementary ceremonies in connection with commemorating one's life levels, complementary ceremonies concerning certain moments in the cycles of time, and the manifestation of the urge to reveal mere beauty (Hui \& Lau, 2006; Karakelle, 2009; Zillmann, 1995).

Indonesian people who adhere to ancestral beliefs then acculturate to the Shiva-Buddhist understanding which is thought to have occurred since the beginning of Christ. Indonesia, which consists of a stretch of thousands of islands, has many folk stories / tales / legends that are told orally, such as the story of Jaka Tarub, Roro Jonggrang, Nyai Anteh (Java Island), Malin Kundang (Sumatra), Raja Pala, I Bawang Teken I Kesuna, Pan Balang Tamak, Men Brayut, Jayaprana Layon Sari (Bali), Putri Mandalika (Lombok), Buen Lajendre (Sumbawa), Oi Mbora (Bima), Watu Maladong (NTT), Legenda Batu Bangga, Hawadiyah, Ila Ga Ligo (Sulawesi), Mandin Tangkaramin, Pangeran Biawak (Kalimantan), and other stories that are scattered throughout the archipelago. Many stories that are still developing to present, it is not uncommon for them to contain figures from among the common people. Thus, this study aims to determine the Pekatik character in the Gambuh Batuan-Gianyar dramatic performance, because in the last 30 years it is rarely performed so that it can provide the benefit of written information about this character.

\section{Materials and Methods}

This research uses qualitative methods, namely describing/exploring, and structurally explaining the object being studied to gain a deep understanding. The data collection techniques in this study apply the techniques of literature review, documentation review, and interviews.

\section{Results and Discussions}

The existence of a servant character (punakawan) in a dramatic performance is very important because this character is a translator, emphasizing a play that is performed using the local language (Balinese) so that it is easily digested by the audience. Condong, penasar, wijil, semar, togog, turas, banyolan are some of the figures who are clerks in dramatic performances in Bali. Performing Gambuh Desa Batuan-Gianyar, Pekatik figure serves as a guardian of the royal horses, his position as a servant/clerk of a kingdom who is an expert in the field of horse training so that he is swift in carrying out his duties. Servant figures in other dramatic performing arts, such as the mask dance, Arja, and Calonarang, are called Penasar Kelihan (punta) and Penasar Cenikan (wijil).

The many Gambuh plays that are performed, not all of them will bring up the Pekatik character because not all stories require its appearance, usually, the Gambuh performance in the Batuan Gianyar village style brings out the Pekatik character in the story of Tebek Jaran (kill the horse) and the Widia Sari War (rank of lasem/autumn lasem). Pekatik (Balinese) or Pakatik/Pangatik as Euis Suhaenah stated that:

Etymologically, pangatik comes from the word Pakatik in the Sundanese dictionary, which means a man who takes care of a horse. The word pangatik sounds unique, it is a local dialect language in the Sumedang regency, the term pangatik in the performing arts of Kuda Renggong is trainer and dancer. Kuda Renggong is a type of traditional West Java art originating from Sumedang Regency which is still popular and is even favored by various social strata of society and has shown its development throughout the ages. Pangatik position in Kuda Renggong art is complementary and cheerful, its presence is very meaningful, as well as musicians in the art of Kuda Renggong is support. Pangatik as a horse trainer, during the reign of the Sumedang regent, Pangeran Aria Suriatamaja, 
was used for prijaji or nobility purposes as a means of transportation. Owners and users of horses are only certain people who are considered rich, merchants, and aristocrats. They are the ones who have the right to use it, while the common people are only the duty bearers to maintain it.

It is clear from the above explanation that the Pekatik character is a servant of the common people who are skilled in maintaining the horses of the king. Its presence is very important for the storyline that is being told. Observations from the author himself and confirmed from the results of interviews, since the 1990s Pekatik's role was no longer involved in a Gambuh Batuan-Gianyar performance. This figure was replaced by the character Semar because to shorten the time and reduce the number of dancers on the stage, that this was also inseparable from the immigration of the Gambuh function from Bebali to the realm of balih-balihan (the art of tourism). The impact of tourism, which wanted a classic spectacle, forced the function of the Gambuh show to leave its function, which was originally a ceremony accompaniment, into a spectacle art, although in some elements of its presentation it used an imitation of the original. From this point of view, the Pekatik character, who initially appeared in the two plays above, has now been replaced by the Semar character who is also the companion of the Panji character. The existence of punakawan figures, in the epics of Ramayana or Mahabharata in Bali, there are several figures of punakawan such as Tualen, Merdah, Delem, Sangut, and in the Gambuh performance art there are also figures known as Togog, Semar, and Turas. In Java, some clown figures, both on the antagonist and protagonist sides, are Semar, Petruk, Gareng, and Bagong. To be more able to animate as a dancer, in Pagambuhan Dharma there is spiritual guidance for Semar/Turas figures as royal servants/clerks, both as a means of asking for safety and as a means of summoning the power of taksu for the dancer. Widjaja Bandem (2012: 10, 18-19) stated:

Pangasren Semar, Turas wenang, sing srana wenang.

Idep ku Aji Semar, angubah Smara, angirut Smara, lunga den tangisin, sungsung guyu ring swaranku, ajur-ajer ring solah, teka geger, teke rena, Ah Ah Ah Sih.

Translation:

Pangasren Semar is also for Turas. The means used can be anything. Focus on the knowledge of Semar, change romance, stimulate love, if you separate you will cry, greeted with a sweet smile I say, graceful in my dance, to be in an uproar, to be satisfying, Ah, Ah, Ah, dear.

\section{Use of Antawacana}

Pekatik characters in their dialogues use Balinese, which includes Balinese sor, alus singgih, alus sor, or alus mider because their usage is adjusted to who is having the dialogue. One important thing, this character must also understand and understand Kawi language, because in several scenes he will have a dialogue with the main character who uses Kawi language. In Balinese, Zurbuchen (1981) stated the language world of Bali is one remarkable richness and diversity in all its spoken, written, sung, and chanted manifestations. Balinese is an Austronesian language of the Malayo Javanic subgroup and is related to the language of Bali's closest island neighbors Lombok, to the east, and Java, lying to the West. Esser groups Balinese with Sasak of Lombok and Sumbawa of Western Sumbawa based on phonological correspondences, making Balinese part of an Eastern Indonesian sub-grouping.

The above statement is that the Balinese language has a characteristic that is part of the Malay family language, both spoken orally and in writing with the Balinese script. Regarding the way of speaking the language, an interview with I Made Suteja stated that the daily dialogue with the dancer's dialogue on the stage is not the same, because in a show a dialogue has been processed into a performance language that contains aesthetic values. The aesthetic value can be listened to through tempo (fast-slow), intonation (high-low), volume (small-large), voice character (loud-soft) (interviewed, 28 December 2020). Below is an excerpt from the antawacana/dialogue Pekatik with Semar, and the character Pekatik with Panji.

Pekatik (P) with Semar (S):

$\mathrm{S}$ : Jero-jero pekatik, Kija lakunne?

(You're pekatik, where is he?)

Budiarsa, I. W. (2021). Pekatik in gambuh dramatic show. International Journal of Linguistics,

Literature and Culture, 7(3), 172-179.

https://doi.org/10.21744/ijllc.v7n3.1589 
$\mathrm{P}$ : Tityang paman Semar.

(I am Semar's uncle)

$\mathrm{S}$ : Tityang kanikain ngedannin jeronne, apang presida sayageyang kuda druwenne.

(I was asked to call you, to quickly prepare his horse).

$\mathrm{P}$ : Indik kuda ida dwagung putra, sampun sayaga antuk tityang.

Kuda druwenne sampun neda, taler sampun kepandussin.

Durus panumaya mangkin ida pacang lunga?

(Regarding the prince's horse, it is ready by me. His horse has eaten and has been washed. Will he leaves today?)

S : Payu, dinane jani ida dwagung putra pacang lunga ke puri Gegelang.

(So, today the prince will go to the kingdom of Gegelang).

$\mathrm{P}$ : Yenning durus, banggyang tityang nangkil ring ida dwagung putra.

(If so, let me face him).

$\mathrm{S}$ : Nah, nahh.. lamun keto sayagayang.

(Yes, yes .. then be prepared).

Pekatik (Pk) with Panji (Pj):

$\mathrm{Pk}$ : Nunas lugra tityang ratu dwagung putra. (My dear prince)

$\mathrm{Pj}$ : Lah ya ta kita Pekatik.

(O you Pekatik)

Pk : Tityang ratu dwagung putra. (my master's servant)

$\mathrm{Pj}$ : Harepan ta ingsun mangke, bipraya rumujug haneng puri Gegelang. Kang kadi punapa ikang kudan ingsun?

(My current wish, will go to the Gegelang kingdom. How is my horse ready?)

Pk : Sampun sayaga ratu dwagung putra, indik kuda druwenne Ki Dalang Anteban.

(Daulat, it's ready my lord, Ki Dalang Anteban's horse is ready).

$\mathrm{Pj}$ : Yanning tun mangkana gargita twas ingsun,

Ingsun bipraya anunggang kuda rumujug haneng puri Gegelang.

(If so how happy I am, I will ride a horse to the kingdom of Gegelang).

Pk : Ainggih ..durus-durus ratu dwagung putra.

(daulat, silakan-silakan tuanku pangeran).

(interviewed with I Wayan Jering, 26 December 2020).

Regarding the narrative of the results of the above interview, the Pekatik character uses Balinese alus singgih as his lord, while dialogue with Semar uses Balinese sor or alus madya. It is necessary to understand the use of anggahungguhing basa so that there is no overlap when dialogue on the stage is based on the degree of the interlocutors. As Zurbuchen (1981) stated that:

...Balinese speech cannot be compared to a train that switches between one or another of various parallel "tracks". It is rather a continuous movement along a continuum of moreor-less, where different points in an utterance may show reciprocity, deprecation, or respect. The term "language levels" implying absolute and discrete oppositions in utterances, rather than just within the lexicon, is in this sense misconceived. The Balinese feel that speech can be directed "up" and "down" at the same time. Their image of language evokes the waves and contours of utterances which delineate all dimensions of Balinese social space: terms such as anggah-ungguhing basa, tegeh-endek (endep) basa, and sor-singgih basa, which can be translated as "the highs-and-lows of language" do not imply that "high" and "low" are mutually exclusive deprecating vocabularies, although theoretically subdivisions of alus speech, co-occur with kasar vocabulary when the context is appropriate. 
Forms, Make-Up and Clothing

Dibia (2013) stated that fashion is used to show gender identity, social status, character, and dance genre, in addition to adding to the attractiveness of the show. Balinese dance, make-up, and clothing are some of the supporting elements of appearance on stage. This element can provide the identity of the characters/roles that are performed on the stage, and strengthen the character of the dance (Budiarsa, 2020). Regarding this Pekatik character, seen from the shape of his body, he is usually short fat or can be played by a dancer who has a thin and short body, with very simple make-up and clothing as a reflection that the Pekatik character is from the common people. I Wayan Jering stated:

...sekaa Mayasari pregina pekatik e ane tawang nanang I Lekong Tantra ne paling pangus e. Aganne nak bise mase ngigel Demang. Sing je nyacad keto malu, mula adung krana kulitne selem, sing liu payassin sube parekkan ngenah. Mesaut duweg dikalanganne, sing kalah mekanda. Ape buin pejalanne nak mula bungkuk igis. Nanangne pregina, kaki Kuir nyak nurun kebisanne ked bli Lekong, panak cucunne sing ade nerussin (wawancara langsung, tanggal 26 Desember 2020).

\section{Translation:}

... a Pekatik dancer in the Mayasari group who knows I Lekong Tantra which is very suitable. He is also able to dance Demang. It does not mean to discredit, it is appropriate because he has black skin, there is no need to make a lot of makeup because the stature of the people is visible. Good at dialogue on stage, no less material for dialogue. Likewise, the road is a bit hunchbacked. His father was also a dancer, Kuir's grandfather had blood flowing from his art to Lekong's older brother, none of his children and grandchildren inherit him now.

The pekatik dancer must be considered from the above narrative, in terms of determining/selecting his role in the Gambuh performance, because it will be related to the sesaluk criteria, which is one of the supporting elements of a person so that it is appropriate to present dance figures on stage. Mr. Lekong Tantra (deceased) is a pekatik dancer that was once owned by the Gambuh Mayasari Batuan-Gianyar group, which until now no longer displays this role/character in every presentation of the storyline. Regarding make-up and clothing, in Balinese dance, the makeup and costumes of certain figures are indicators that the audience can indirectly know about their social status. The figures of kings, patihs, servants, people, and so on can be known through the clothes they wear, it is also known from the make-up worn on the dancer's faces both in natural and theatrical types of make-up to beautify or change the original face of the dancer according to the character presented.

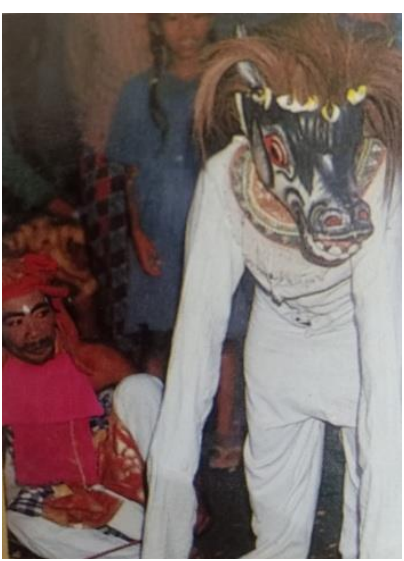

Figure 1. Pekatik and horse

Figure 1 (seated dancer) is a Pekatik character wearing a very simple outfit, consisting of a headband (udeng), wearing a red scarf wrapped around his neck, saput poleng, and white trousers. As for the make-up of eyebrows, red Budiarsa, I. W. (2021). Pekatik in gambuh dramatic show. International Journal of Linguistics, Literature and Culture, 7(3), 172-179. https://doi.org/10.21744/ijllc.v7n3.1589 
cheeks, mustache, and gecek pamor between the bases of the eyebrows. As explained by I Made Suteja, Pekatik's make-up and clothing are very simple, because of his position as a folk figure. The make-up and clothing in the Gambuh drama also have sor singgih (level) usage so that the king and subordinate figures can be distinguished. Concentrated characters with innocent gestures seem better hoes (interviewed, 28 December 2020). From this statement, the Pekatik character indeed requires a careful selection of dancers to get an appropriate body posture, dancer character, and the use of simple costumes as well.

\section{Conclusion}

Some of the dramas that emerged and developed in Bali are stated to have reached their golden peak during the reign of Dalem Watrurenggong (16th century) who sat on Gelgel-Bali. Gambuh is one of them that gets special attention from the king so that this drama becomes the prima donna when the king has a ceremonial procession. In the Hindu concept, the ceremonial procession includes; Dewa Yadnya; holy sacrifices/ceremonies offered before God/Ida Sanghyang Widi Wasa, Pitra Yadnya; holy sacrifices/ceremonies offered to ancestral spirits, Rsi Yadnya; holy sacrifice/ceremony (punia) offered to priests or ceremonial leaders, Bhuta Yadnya; is a holy sacrifice/ceremony offered to the bhuta kala/underworld, and the Manusa Yadnya; holy sacrifice/ceremony aimed at humans to achieve perfection, peace, prosperity, harmony in living life.

Gambuh, which in its development is now functioned as the Bebali dance, is a reflection of the order of life in the keraton/royal palace. Then, this transformation affects the strata of the position of each role on the stage. Pekatik whose position is a servant in the Gambuh Batuan drama show is a character with soft, hard, innocent, and funny characters. As a keeper of royal horses, he wears a simple outfit, with simple make-up as well. The dialogue is delivered in Balinese, which includes Balinese sor, alus; alus madya, alus mider, and alus singgih. The most important thing is that the Pekatik character must also understand the Kawi language spoken by the main character. Since the 1990s, Semar's character has shifted his role to Pekatik. Hopefully, the next Gambuh Batuan performance will appear again, so that the next generation of artists will know the existence of this figure, even the Gambuh Batuan-Gianyar Bali organization/group will be able to produce a generation of Pekatik dancers.

\section{Conflict of interest statement}

The author declared that he have no competing interest.

Statement of authorship

The author has a responsibility for the conception and design of the study. The author has approved the final article.

Acknowledgments

I am grateful to two anonymous reviewers for their valuable comments on the earlier version of this paper. 


\section{References}

Bandem, I. M. (1996). Etnologi Tari Bali. Penerbit Kanisius.

Bastomi, S. (1992). Wawasan Seni. IKIP Semarang Press.

Brysse, K., Oreskes, N., O'Reilly, J., \& Oppenheimer, M. (2013). Climate change prediction: Erring on the side of least drama?. Global environmental change, 23(1), 327-337. https://doi.org/10.1016/j.gloenvcha.2012.10.008

Budiarsa, I. W. (2020). Penciptaan Karya Seni Tari Baris Gede Gentorag. Kalangwan: Jurnal Seni Pertunjukan, 6(2), 84-94.

Demircioğlu, Ş. (2010). Teaching English vocabulary to young learners via drama. Procedia-Social and Behavioral Sciences, 2(2), 439-443. https://doi.org/10.1016/j.sbspro.2010.03.039

Dibia, I. W. (2013). Puspasari Seni Tari Bali. Institut Seni Indonesia Denpasar, UPT Penerbitan.

Formaggia, M. C. (2000). Gambuh: Tinjauan seni, makna emosional dan mistik, kata-kata dan teks, musik gambuh Desa Batuan dan Desa Pedungan (Vol. 1). Yayasan Lontar.

Harris, D., \& Willoughby, H. (2009). Resuscitation on television: realistic or ridiculous? A quantitative observational analysis of the portrayal of cardiopulmonary resuscitation in television medical drama. Resuscitation, 80(11), 1275-1279. https://doi.org/10.1016/j.resuscitation.2009.07.008

Hui, A., \& Lau, S. (2006). Drama education: A touch of the creative mind and communicative-expressive ability of elementary school children in Hong Kong. Thinking skills and creativity, 1(1), 34-40. https://doi.org/10.1016/j.tsc.2005.06.001

Karakelle, S. (2009). Enhancing fluent and flexible thinking through the creative drama process. Thinking Skills and Creativity, 4(2), 124-129. https://doi.org/10.1016/j.tsc.2009.05.002

Sedyawati, E. (1981). Pertumbuhan seni pertunjukan (No. 4). Penerbit Sinar Harapan.

Vickers, A. (2009). Peradaban Pesisir Menuju Sejarah Budaya Asia Tenggara. Denpasar: Pustaka Larasan.

Zillmann, D. (1995). Mechanisms of emotional involvement with drama. Poetics, 23(1-2), 33-51. https://doi.org/10.1016/0304-422X(94)00020-7

Zurbuchen, M. S. (1982). The shadow theater of Bali: explorations in language and text.

Budiarsa, I. W. (2021). Pekatik in gambuh dramatic show. International Journal of Linguistics, Literature and Culture, 7(3), 172-179. https://doi.org/10.21744/ijllc.v7n3.1589 